\title{
A profession selling out: lamenting the paradigm shift in physician advertising
}

\section{N D Tomycz}

$\mathrm{F}$ or generations following the first American Medical Association (AMA) Code of Ethics in 1847, the relationship between doctors and advertising remained unambiguous-advertising was forbidden. In 1975, however, the Federal Trade Commission (FTC) accused the profession of "restraint of trade" and legally persuaded doctors to permit advertising amongst their clan. As the 1970s witnessed the relentless burgeoning of healthcare expenditure, physicians accepted the blame for immuring themselves from the natural forces of economics. American physicians were bullied to embrace advertising under the delusion that doctoring-like any trade-would become better and cheaper if incited by competition. Today most American physicians engage in some form of paid advertising, yet it is doubtful that physician advertising has either augmented the quality or diminished the cost of health care. Advertisement has eroded medical professionalism by denying doctors the right to enforce ethical boundaries between themselves and the "let the buyer beware" world of business. And more is at stake than professional status, for the doctor/patient relationship, the cornerstone of medicine, is endangered as physicians continue to cast forth the self interested lure of advertisement.

To assume that for over 130 years physicians anathematised advertising for purely ethical reasons would be naive. Sociologist Paul Starr explains that in the early 19th century, no group "embraced the ways of the market as actively as did popularisers, alternative healers, and quacks". ${ }^{1}$ Advertisement was perhaps the most successful implement of empirical medicine. So it is no surprise that professional licensed doctors in America grew up with a "distaste and discomfort for advertising". ${ }^{2}$ Medical advertisements were especially potent in the self reliant Jacksonian era, which touted health as a do it yourself venture commodified into tonics and one time procedures. To distinguish themselves from the circus of healthcare providers, physicians not only instituted higher educational standards and licensure but also demanded that their members refrain from advertising to the masses. Thus, the early divorce of professional medicine and advertisement may have been as much about public relations as about ethics.

Nevertheless, it was significant that the members of the medical profession framed their aversion to advertising as an ethical objection. According to the first AMA Code of Ethics (1847), it was "derogatory to the dignity of the profession ...to resort to public advertisements" ${ }^{3}$ Licensed doctors took a vow not to advertise because of a collective agreement that it was ethically incompatible with patient care. To promise cures or to publish testimonials violated medicine's commandments, resulting in strict censure and ostracism from the profession. Abstinence from advertisement thus for many decades survived as an unchallenged criterion in defining the American medical professional. Physicians guarded their profession from advertisement and their right to exert such internal control was not questioned. Before the 1960s and 70s, doctors were trusted to construct their own professional boundaries and they were relatively free from outside interference with their clinical activities. ${ }^{4}$ After the successful FTC suit in 1975 (Goldfarb $v$ Virginia State Bar), the AMA removed all prohibitions to advertising, retaining only a weak restriction against false or misleading advertising.

Medicine has in the past been regarded as the epitome of professions. Members of professions typically share specialised knowledge and possess certain technical expertise. Yet what separates a profession from a trade is codified ethicsprofessional behaviour is internally anchored by enforced ethical principles. Professionals in return procure from the public a special magnitude of trust. Professor Allen Dyer claims that identifying someone as a professional "ultimately depends on the ability to trust that individual with personal matters". ${ }^{5}$ A professional's work is buttressed by considerable trust even during a first encounter because of the belief that this individual-by virtue of being a professional-is bound by ethical rules that prevent the exploitation of his or her knowledge and skill. A professional is one individual in society who is not trying to sell you anything; an individual who has at least sacrificed the semblance of profit making ambition in order to enjoy a private relationship with others that is free of consumer scepticism. Therefore, opening the doors to physician advertising threatens the professional status of doctoring by denying physicians as a group the right to coalesce around a set of unifying ethical beliefs. Advertising is a divisive force that pits individual against individual, weakening the common ethical calling that is intrinsic to a profession. The view that advertisement was inappropriate for professionals was not exclusive to medicine, for many other groups, including the American Bar Association, prohibited advertising in the early 20th century ${ }^{6}$ Trust is indispensable to the intimacy and invasiveness of doctoring; advertising undermines the ability of physicians to welcome patients into a safe haven of trust, where respect for the patient is perpetually reaffirmed by a sotto voce approach to solicitation and compensation.

Unfettering doctors to advertise with impunity has propelled the metamorphosis of the medical profession into a trade; and this was perhaps what many in the FTC had in mind back in 1975. Michael B Pertschuk, the FTC chairman during the AMA advertising suit, declared that a "way to control the seemingly uncontrollable health sector could be to treat it as a business and make it respond to the same marketplace influences as other American business and industries". ${ }^{5}$ In addition to disputing the AMA's right to forbid advertising among physicians, the FTC at the same time challenged other ethical restrictions within the AMA, including restraints on the corporate practice of medicine and income sharing arrangements between physicians and nonphysicians. ${ }^{7}$ The FTC suit against the AMA thus appears to

Abbreviations: AMA, American Medical Association; FTC, Federal Trade Commission 
have basically opposed any restrictions that kept physicians from behaving like entrepreneurs within a free market. The mere fact that the suit was one of "antitrust" implies that physicians were already being viewed as cogs in the big business of health care. Years later, L Barry Costillo of the FTC revealed the commission's perception of health care as a "commercial marketplace in which goods and services are bought and sold". ${ }^{8}$

The doctor/patient relationship is not simply theoretical in nature but rather exists as a truly unique and compassionate collaboration. Ezekiel Emanuel teaches that trust is the quintessential element of the ideal doctor/patient relationship. ${ }^{9}$ Although doctors certainly have financial interests in their work, advertising can make this interest so palpable and conspicuous that it may compromise the trust on which doctors and patients rely. Mark Yarborough cautions that advertising may transform the doctor/patient relationship "primarily into a means of making money rather than a means of serving and promoting the best interests of the patient as determined by the patient $t^{\prime \prime} .{ }^{10}$ Moreover, Emanuel insists that a productive relationship requires that patients are able to tell their physicians "what kind of information they want and do not want to know". ${ }^{\prime}$ Physician advertising is one-way communication in which the patient does not participate. If a doctor tried to read an advertisement to a patient face to face, he or she would most likely not finish before the patient interrupted, wanting clarification and elucidation of the risks. Moreover, Americans overwhelmingly demand the freedom to choose among possible treatment options as well as among primary care physicians and specialists. Physician advertising manipulates choice by presenting limited and biased information that aims to entice rather than inform. Advertisements often fail to cite complications and rarely present treatment alternatives not offered by the physician. The fleeting medium of advertisement-billboards, short radio segments, fliers, rapid television infomercials-is not appropriate for initiating the informed and often complex decision making process that should underlie all health interventions. Finally, one is left to ponder how patients can make decisions in their best interest when exposed to the worst of physician advertising, which associates certain interventions with luxury, beauty, or esteem.

In addition, physician advertising may increase the cost of health care and create unrealistic expectations that will further weaken the relations between doctor and patient. Dr Robert Geist and Dr Howard Ward point out that the price of advertising will augment physician overheads and be transferred to the public. ${ }^{71}$ Moreover, Mark Yarborough warns of an "additional hidden cost to physician advertising" when misleading advertisements generate suits and force doctors to transfer higher malpractice premiums to the public. ${ }^{10}$ Finally, one must remember that trust goes both ways. Physicians tend to trust that patients who are satisfied with the prescribed treatments will continue to return as is necessary. If advertising encourages patients to frequently change doctors and shop around for the best deal, physicians may exert less effort to establish a strong interpersonal relationship with patients.

To exemplify the problems that arise when doctors advertise, one can turn to even that seemingly innocuous workhorse of physician advertisement, the Yellow Pages. Through an analysis of phonebook listings by hundreds of physicians, Dr Julia Reade and Dr Richard Ratzan revealed that about $12 \%$ of "specialists" in the Yellow Pages were not board certified. ${ }^{12}$ Moreover, many physicians are listing themselves as specialists in fields-such as hypnosis and nutrition-for which no specialty board certification exists. ${ }^{12}$ Specialty advertising in the Yellow Pages is therefore frequently deceptive; patients are being misled into believing that they are receiving expert care. Because the FTC rendered local medical societies impotent with respect to advertisement regulation, medical associations "can only suggest to members that they adhere to advertising guidelines" ${ }^{12}$ Advertisements can too easily take advantage of the public's ignorance regarding what one needs to be a true medical specialist. Even simple Yellow Pages words like "safe" and "effective" may prove to be legal Achilles tendons because of variable interpretation.

Finally, a meaningful doctor/patient relationship requires that the doctor appreciate the delicate role of being a patient. Patients are not consumers in search of a commodity. There is a unique vulnerability that comes for want of relief from disability and disease, and patients are unlikely therefore to be capable of defending themselves with the incredulousness they may normally bring to other forms of advertising. Advertisement becomes maximally seductive when priceless intangibles such as "feeling good" and pain relief are showcased to a suffering population. It is simply disrespectful to accost the medical ignorance, insecurities, and fears of patients with persuasion and titillation. There is simply no single variable with which one can measure physicians in order to determine who is the best for a particular patient, and it will be unfortunate if the public begins to associate the quality of a doctor with the quality of his or her advertisements. The humility that should accompany the privilege of treating patients is lost when physicians invest in self aggrandisement.

If American medicine has lost some of its prestige in the last few decades, perhaps it is because the best advertisement for physicians was the original decision not to advertise. In countries such as Germany and Italy, the ban on physician advertising persists; however, in America, doctors have been legally liberated to commercially promote themselves. Perhaps physicians were resented for acting as if their members were too noble to dirty their hands with business behaviour. But the prohibition against advertising was not based on ethical superiority. Doctors recognised early on that medicine did not end with the distribution of a pill but required the formation of productive relationships buttressed by an indispensable trust. Now that medical quackery has returned with unprecedented sophistication, annually draining billions from the population with unproven treatments and supplements, physicians may be more tempted than ever to advertise and secure some piece of the healthcare pie. Yet no matter what the law permits, advertisement in medicine should remain a taboo that unifies doctors in the defence of professionalism and the unique covenant they share with patients.

Correspondence to: N D Tomycz, 5512 Centre Ave \#1, Pittsburgh, PA 15232, USA; tomycznd@upmc.edu

Received 25 April 2005

Accepted for publication 9 May 2005

\section{REFERENCES}

1 Starr P. The social transformation of American medicine. New York, NY: Basic Books, 1982.

2 Physician advertising: Ohio physicians speak out after a decade of change. Ohio Med 1991;87:68-72.

3 American Medical Association. AMA Code of Ethics, 1847, www.amaassn.org/ama/upload/mm/369/1847code.pdf (accessed 25 Jun 2005)

4 Burnham JC. American medicine's golden age: what happened to it? In: Leavitt JW, Numbers R, eds. Sickness and health in America, readings in the history of medicine and public health. Madison, W: University of Wisconsin Press, 1985.

5 Dyer AR. Ethics, advertising, and the definition of a profession. J Med Ethics 1985; 11:72-8.

6 Andrews LB. Birth of a salesman: lawyer advertising and solicitation. Chicago, IL: ABA Press, 1980. 
7 Ward HN. Professional medical advertising. J Kansas Med Soc 1979;80:436-44.

8 Costillo LB. Antitrust enforcement in health care: ten years after the AMA suit. New Engl J Med 1985;313:901-4.

9 Emanuel EJ, Dubler NN. Preserving the physician/patient relationship in the era of managed care. J Am Med Assoc 1995;273:323-9.
10 Yarborough M. Physician advertising: some reasons for caution. South Med J 1989;82:1538-44

11 Geist RW. Advertising in medicine-a physician's perspective. New Engl J Med 1978;299:483-6.

12 Reade JM, Ratzan RM. Yellow professionalism: advertising by physicians in the Yellow Pages. New Engl J Med 1987;316:1315-19.

\section{bmjupdates+}

bmjupdates+ is a unique and free alerting service, designed to keep you up to date with the medical literature that is truly important to your practice.

bmjupdates+ will alert you to important new research and will provide you with the best new evidence concerning important advances in health care, tailored to your medical interests and time demands.

Where does the information come from?

bmjupdates+ applies an expert critical appraisal filter to over 100 top medical journals A panel of over 2000 physicians find the few 'must read' studies for each area of clinical interest

Sign up to receive your tailored email alerts, searching access and more...

www.bmjupdates.com 